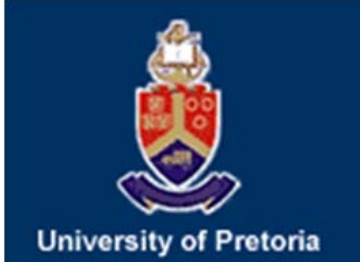

University of Pretoria Department of Economics Working Paper Series

\title{
A Categorisation and Evaluation of Rhino Management Policies
}

Douglas J. Crookes

University of Pretoria

James N. Blignaut

University of Pretoria

Working Paper: 2015-13

March 2015

Department of Economics

University of Pretoria

0002, Pretoria

South Africa

Tel: +27 124202413 


\title{
A categorisation and evaluation of rhino management policies
}

\author{
Douglas J. Crookes* and James N. Blignaut ${ }^{\dagger}$
}

March 3, 2015

\begin{abstract}
Rhino populations are at a critical level and new approaches are needed to ensure their survival. This study conducts a review and categorisation of policies for the management of rhinos. Twenty seven policies are identified and classified into in situ (reserve based) and ex situ (market based) policies. The policies are then evaluated based on four target areas: poachers/hunters; consumers; intermediaries and the game reserves themselves. The study finds that protected areas management policies seem most beneficial in the short run, in particular the enforcement of private property rights over resource utilisation, as well as the establishment of wildlife sanctuaries that act as sustainable breeding grounds for rhino populations.
\end{abstract}

Keywords: rhino, economics, property rights, tragedy of the commons

\section{Introduction}

The threat of the ongoing and intense levels of rhino poaching on the continued survival of rhinos around the world is a cause of great concern (Kagande \& Musarurwa, 2014). South Africa is regarded as the major custodian of the world's remaining African rhino populations ('t Sas-Rolfes, 2012), conserving 93 percent of Africa's White Rhino population and 41 percent of Black Rhinos alive today (Emslie \& Knight 2014). Rhino horns, made of keratin, are a sought after commodity on the Asian markets, notably Vietnam and China (Milliken \& Shaw, 2012) and is used in traditional medicine, hence the market for rhino horns. Rhino horn poaching in South Africa has escalated dramatically in the past 5 years. In 2013, 1004 rhinos were poached, up from 83 in 2008 (DEA, 2014). If such trends continue, South Africa's free roaming rhino population

*Corresponding Author. Department of Economics, University of Pretoria, Private Bag X20, Hatfield 0028, Email: dcrookes@outlook.com

${ }^{\dagger}$ Department of Economics, University of Pretoria, Private Bag X20, Hatfield 0028, Email: jnblignaut@gmail.com 
could be extinct in the next 20 years (Di Minin et al., 2015). Radical solutions are required to stem the illicit slaughter of these majestic animals.

Much of the current debate around rhino management and associated policy recommendations are based on economic principles (e.g. Bulte \& Damania, 2005; Biggs et al., 2012; Collins et al., 2013). In that regard a number of policy instruments have been recommended to either change the behaviour of market participants, the behaviour of intermediaries or the behaviour of poachers. At the same time, traditional wildlife management policies that include in situ management of wildlife resources should certainly not be neglected. The challenge, therefore, is to analyse policies within a holistic framework (Kagande \& Musarurwa, 2014) which takes both economic as well as traditional wildlife policies into consideration, as well as the different participants in the rhino horn supply chain. One way of doing this is by drawing on the literature of illegal exploitation (Clark, 1990). The literature of illegal exploitation emphasises, amongst others, the modification of hunter incentives, and illegal exploitation as an economic activity (Milner-Gulland and Leader-Williams 1992). The literature is therefore aligned with the current economic emphases in rhino conservation, while at the same time expounding on the contribution of in situ management of natural resources.

The approach of this study, therefore, is to identify, categorise and evaluate policies for rhino conservation across a wide range of target groups and type of policies. While most research so far has focussed on one or a few aspects of rhino management, this article makes a unique contribution to the literature by using a holistic framework that takes into consideration wildlife, bio-economic and economic policies drawn from the abovementioned literature of illegal exploitation. The approach followed is as follows: first, a framework for categorising policies is presented; second, a selection of policies from each policy category is discussed with reference to rhino conservation; and third, recommendations are made on the way forward.

\section{Typology of wildlife policies}

The framework used to classify different rhino conservation policies is based on Crookes and Milner-Gulland (2006). This framework considers firstly the incidence of the policy (who is targeted - consumers, game reserves or poachers), then provides an example of the policy, and then asks a number of key questions associated with each category of policy (see Table 1). Although the article of Crookes and Milner-Gulland (2006) provide the basic framework for analysis, this framework was originally developed with bushmeat in mind. The framework therefore needed to be modified and greatly expanded to incorporate a range of policies suitable for rhino management.

In considering the Table, policies include direct market interventions, protected areas management, hunter behaviour modification, and livelihood and intermediary behaviour modification. In the case of market interventions, two policies are identified, supply interventions and demand interventions. Under 
demand interventions, policies include education, price controls, income modifications, and toxic treatment of horns. The key policy questions include whether the policy affects the use of rhino horns by consumers in Asian countries. Under management measures for game reserves, policies include establishing private property rights, establishment of buffer zones, source sink policies, de-horning, DNA profiling, rhino relocation and the genetic breeding of hornless rhinos. The main policy questions include whether or not supply is affected. Policies targeting hunters/poachers affect hunter behaviour, and includes quotas, hunting seasons, gear restrictions, species restrictions, enforcement, penalties/prison sentences and shoot to kill. The nature of the policy used is dependent on whether or not rhino hunting is legal. For example, if hunting is illegal then quotas and hunting seasons would not be applicable and more stringent policies such as steep prison sentences and even shoot to kill policies may be more applicable. Finally, the framework identifies mitigation measures that affect the whole supply chain. These include the promotion of alternative livelihoods. These policies would not be sufficient in and of themselves to reduce rhino poaching, but rather used in conjunction with other policies.

The table provides a framework for a meta-analysis of policies. Policies are defined very broadly in this study to encompass all intentional acts that aim at affecting the behaviour of target groups. Therefore, both international, national, provincial and local legislation, as well as non-legislative policies such as "moral suasion", and includes both the legislative instrument as well as the "will" by all parties to adhere to the policy (see e.g. McHenry, 1993). The policies target four groups, consumers, game reserves, hunters/poachers, and the whole supply chain. Although it identifies 27 potential policies, these are in fact clustered within two groups, in situ policies and ex situ policies. By in situ policies, we mean policies aimed at the hunting locality itself, and includes policies of game reserves as well as hunters/poachers. Ex-situ policies are those aimed at the markets. We will now consider how these relate to rhino conservation.

\section{Application to rhino poaching}

\subsection{Ex situ (Market) policies}

Market policies are those that target Asian consumers of rhino horns. Two market policies are discussed in greater depth: trade bans and consumer behaviour modification.

The Convention on International Trade in Endangered Species established a trade ban on rhino horn in an attempt to reduce the demand (CITES, 2013). However, it seems that rising incomes in Asian countries, in particular Vietnam (Figure 1), are actually increasing demand (Milliken \& Shaw, 2012). Consequently, the price of rhino horn has risen so dramatically that it rivals the value of other high value goods such as gold and narcotics (Biggs et al. 2012). The standard economic argument for lifting the trade ban is that the resultant increase in rhino horn supply would flood the market, thereby reducing its price. 
However, the trade ban, in its current form, has not been effective in reducing supply.

While lifting the trade ban attempts to target consumer demand through price, another means of targeting consumer demand is by affecting behaviour (Litchfield, 2013). This is achieved by educating consumers through, for example, marketing campaigns that highlight the negative aspects of poaching or demonstrating the absence of any medical benefits of rhino horns.

As noted previously, the important question here is whether these policies will affect consumer behaviour. The reality of the situation is that the effect of such policies on demand is uncertain (Collins et al., 2013). Given the uncertainties and therefore risks associated with these and other market policies it is necessary to consider other policy options as well. It is thus necessary to consider in situ management options that target poachers and traders directly. These will be considered in the next section.

\subsection{In situ management}

In situ management consists of both protected area management as well as hunter behaviour modification. The difference between these two is that the first is implemented by reserve managers while the second is enforced by wildlife authorities. Under protected area management, two policies will be discussed: extreme command and control measures, and enforcing private property rights. Another in situ policy is also briefly discussed, namely hunter behaviour modification.

Command and control measures target poachers directly by using military style tactics to track, identify and, if necessary, eliminate poachers in protected areas. The extreme measures proposed by Kalron (2013) include doing away with scientific services at game reserves and establishing fully equipped military centres for combatting poaching. Command and control measures also include the use of biotechnologies such as acoustic traps, mobile technology, mikrokopters, radio frequency identification tags, encrypted data digital networks, camera traps, DNA testing, radio collars, metal scanners, and satellite imagery (UNEP, 2014). Shoot to kill strategies are argued by some (e.g. Messer 2010 ) as the only viable policy in low income countries with high economic benefits from endangered wildlife.

Command and control policies represent one in situ policy. Another is private property regimes. Hardin's 'tragedy of the commons' (Hardin, 1968), developed more formally in the Gordon-Schaefer bio-economic model (Clark, 1990), argues that 'commons' or open access harvesting produces less than optimal resource use compared with private property regimes. Although the theory has its criticisms, most of these criticisms revolve around the definitions of 'commons', where the definition of common pool resources (CPRs) are much broader than the open access definition of commons implied by Hardin, and includes communal resources that would not necessarily be subject to Hardin's theory (Hardin 1998, Ostrom et al. 1999). The important point of the theory is not the management regime that is in place, but rather the nature of the resource management 
that occurs within such a system that defines the nature of the CPR (Edwards \& Steins 1999). In spite of criticisms, the theory remains relevant. In a review of Hardin's theory 22 years later, Feeny et al. (1990) conclude that "in the intervening years, the ideas that Hardin popularised have become the most widely accepted explanation for overexploitation of resources that are currently held" (p.2).

Hardin's theory can be represented as follows: the open access solution is at a lower level of stock than the profit maximising solution, and also the biological optimum of maximum sustainable yield. What this means is that a regime that is based on private property provides a more sustainable wildlife population compared with management levels based on open access and even biological principles. Although rhino populations are under both private and public management, in many cases, because of porous borders and large patrol areas, the implicit resource management regime may be regarded as open access (see also Bulte 2003). Therefore, the theory predicts that the enforcement of private property rights may result in a more optimal solution for rhino management.

The major consequence to emerge from Hardin's tragedy of the commons theory is therefore that resources should not be managed as open access resources but rather that private property rights should be enforced. This can be explained with the example of a house. If there are valuables inside a house the private owner's rational response is to ensure that sufficient security is in place to keep intruders out. Unfortunately, because of the size of many reserves private property rights are difficult to enforce, and resources are effectively managed as 'common property', even though they might be 'private'. An example is the large Transfrontier parks between South Africa and a number of its neighbouring countries. While these Transfrontier parks had the benefit of providing greater rangeland areas for South Africa's megafauna, the removal of fences allowed free access to poachers of South Africa's wildlife resources. Kruger National Park, one such Transfrontier park, has the highest incidences of rhino poaching in South Africa, namely 60 percent of all rhinos poached in 2013 were from this reserve (WESSA, 2014). But this is the case not only in the public sector but also the private sector. An example is Sabi Sand game reserve, a reserve abutting Kruger National Park comprising 8 private game farms (Stay in Africa, 2014), with no fences between the farms and no fences between the game reserve and Kruger National Park (AndBeyond, 2014).

A third form of in situ management involves modification of hunter behaviour, for example through the imposition of hunting seasons, species restrictions and gear restrictions (i.e. only allowing a certain type of firearm to be used). In general these types of policies, although widespread in the fisheries industry, are less effective in the conservation of rhinos given the difficulties in enforcing these policies.

These type of policies are likely to be far more effective at reducing the supply of rhino horn to Asian markets. It is crucial, however, that social upliftment programmes also target poachers and their families. This will have the added benefit of reducing the incentive to poach. 


\section{Evaluation}

While it is not possible to evaluate all policies within the present study, we may evaluate each broad category, namely those targeted at poachers, game reserves and consumers, and the whole supply chain.

\subsection{Game reserves}

We develop a simple Gordon-Schaefer model for assessing the effects of varying policies (prices for horns, costs) on rhino abundance. It is then possible to estimate the equilibrium level of poaching effort under different property rights regimes. Under private property, revenues are maximised when marginal revenue $(\mathrm{MR})$ equals marginal costs $(\mathrm{MC})$. Marginal revenue occurs when:

$$
M R=p q k\left(1-\frac{2 q E}{r}\right)
$$

Where $\mathrm{p}$ is the price of rhino horns, $\mathrm{q}$ is the catchability coefficient, $\mathrm{k}$ is the carrying capacity of rhinos, $\mathrm{r}$ is the intrinsic growth rate, and $\mathrm{E}$ is the poaching effort. Thefore the greater the poaching effort the higher the marginal revenue accruing to poachers.

Marginal costs are equal to cost per unit effort c. Equating and re-arranging gives:

$$
E_{\pi}^{*}=\frac{r}{2 q}\left(1-\frac{c}{p q k}\right)
$$

Because r, q, p, c and $\mathrm{k}$ are all constants, under this simple model effort converges on an equilibrium value, and is a function of those variables. For example, if the price of rhino horn increases, then equilibrium effort increases. Conversely, if costs increase then equilibrium effort declines.

Open access effort $\left(\mathrm{E}_{O A}\right)$ is found by equating average revenue (AR) to average costs $(\mathrm{AC})$. The equation is:

$$
E_{O A}=\frac{r}{q}\left(1-\frac{c}{p q k}\right)=2 E_{\pi}^{*}
$$

Therefore, the open access effort is at twice the profit maximising effort, as predicted by Hardin's tragedy of the commons theory. Using unpublished data on rhinos we are able to provide a preliminary indication of the equilibrium levels of effort.

Under the profit maximisation regime, effort is 679 trips, whereas under open access this is 1358 trips. The 2013 effort was 1004 trips. This suggests that the enforcement of private property rights could have a significant impact on poaching effort, and even result in the maintenance of rhino populations. Rhino abundance under open access is 54 individuals, which is below the minimum viable population (MVP) for survival (Traill et al 2010). Under private property rights, rhino abundance increases to 58 percent of the 2013 rhino population, which is a decrease but nonetheless at a sustainable level. 


\subsection{Poachers}

Building on the analysis in the previous section, it is possible to assess the effects of varying the cost price ratio on rhino abundance at equilibrium. Open access equilibrium populations are at:

$$
X_{O A}=\frac{c}{p q}
$$

Where c, p and q are defined as before. Rhino populations under open access are therefore a function of the cost price ratio and the catchability coefficient $q$. And under maximum economic yield, equilibrium rhino population are found at:

$$
X M E Y=\frac{1}{2}\left(\frac{c}{p q}+k\right)
$$

Therefore, using optimisation it is possible to calculate what the cost price ratio under open access would need to be to equate to the profit maximising solution. This is estimated to be 0.583 , in other words that costs need to be at least $58 \%$ of prices for the profit maximisating solution to be achieved. Although current estimates of cost price ratios for poachers are anecdotal, indications from the literature suggest that this could be much lower. Data from MilnerGulland (1999) shows that the cost price ratio for poachers could be closer to 0.02 , implying that large changes in poacher costs and prices would be needed to achieve the same thing that could be achieved through the enforcement of property rights regimes.

\subsection{Consumers}

Policies aimed at consumers are less easy to evaluate. For example there is a growing body of literature that argues that the trade in endangered species is characterised by an Anthropogenic Allee Effect (e.g. Hall et al 2008). This implies that the demand curve is positive for at least for certain price ranges. Under such circumstances, demand reduction strategies could actually increase yields (Figure 2). Furthermore, low international transport costs could actually require massive reductions in yields to offset poaching, as observed with the ivory trade ('t Sas-Rolfes et al. 2014). Furthermore, rhino horn is used for a range of different uses in Asian markets, such as traditional Chinese medicine (TMC) as a status symbol, and as a food supplement (Milliken \& Shaw 2012). These different uses contribute different psychological benefits to consumers that are difficult to disentangle. Therefore, it is important to ascertain the true nature of the demand for rhino horn before such policies can be evaluated

\subsection{Intermediaries}

The supply chain for rhino horn is characterised by a complex network of poachers, exporters, wholesalers and retailers. Poachers and exporters are in country, while wholesalers and retailers are abroad, although this is a simplistic representation as there are a number of additional intermediaries involved, such 
as couriers, buyers and sellers (Milliken and Shaw, 2012). Although Vietnam is the primary recipient of South African rhino horns, trade links include OR Tambo airport (Johannesburg) Maputo International airport and the port of Beira (Mozambique), as well as destinations such as Bangkok (Thailand), Laos, Hong Kong, and China (Milliken and Shaw 2012).

The data suggests that the bulk of the earnings from rhino horns accrued to the retailers during the 1990s, but, more recently, the earnings of poachers, exporters and particularly wholesalers has increased dramatically (Table 2 ). Given these high prices, and a preliminary indication that the costs associated with transportation of goods are low (see previous section) and probably declining as better networks are established, we can hesitatingly conclude that price and cost modification strategies are less effective now than they were in the 1990s. However, given the complexities of these intermediary networks, further research in this area is required.

\section{Discussion and conclusions}

This study has highlighted a number of policy categories: market (ex situ) interventions, and in situ interventions and policy mitigation measures. The market interventions, we found, are at this stage untested, the outcomes uncertain and hence introducing a significant degree of risk and therefore require extreme caution before implementing.

Hunter behaviour modification (an in situ intervention) may be suitable for legal hunting and on private land. However, the vast number of rhinos killed are done so illegally and on state land. Therefore, behaviour modification may be less relevant in the context of the rhino horn trade.

Protected area management policies (an in situ intervention), seem to hold the most promise at present in the absence of better knowledge of market dynamics. One policy is already being implemented, namely poacher tracking and apprehension. Our evaluation of policies indicates that a second protected area management strategy, namely the establishment of private property rights, seems very promising and should actively be pursued.

Recent studies have indicated that while African protected areas have generally been successful in maintaining habitats, they have been less successful in mitigating the effect of human-induced declines in large mammal populations (Craigie et al 2010; Geldman et al 2013; Lindsey et al. 2014). The improvement of protected areas networks, for example through the enforcement of private property rights, is a crucial to ensure the sustainability of species populations. Spatial management of wildlife has in some instances been advocated (McCullough, 1996). One way of achieving this is through the development of wildlife sanctuaries that act as breeding 'sources' for the re-establishment of wildlife populations (Arcese and Sinclair 1997; Hansen \& DeFries, 2007), and animals are translocated to less productive areas or areas where hunting is allowed (so called 'sinks'). However, this policy is highly dependent on wildlife managers being able to prevent poaching in 'source' areas (Bennett \& Robinson, 2000), 
especially given the higher densities of rhinos in those areas. A second issue is persuading hunters to by-pass more convenient hunting areas and travel further afield to hunt in 'sink' areas (Wilkie \& Carpenter, 1999).

The development of wildlife sanctuaries appears to have had at least some beneficial effect on rhino conservation (Kagande and Musarurwa, 2014). It is important to emphasise, however, the need to reduce the impact of policies on communities dependent on poaching for income. We propose, for example, game reserve co-management or at least involvement by communities in decisionmaking processes, as well as the promotion of alternative livelihood activities such as livestock farming, game farming or other economic activities.

\section{References}

[1] ANDBEYOND, 2014. Sabi Sand Game Reserve. Available at: http://www.andbeyond.com/south-africa/places-to-go/sabi-sand-gamereserve.htm (Accessed: 2 July 2014).

[2] ARCESE, P, AND SINCLAIR, ARE, 1997. The role of protected areas as ecological baselines. J Wildl Manag 61: 587-602.

[3] BENNETT, EL \& ROBINSON, JG, 2000. Hunting for Sustainability: The Start of a Synthesis in Robinson, JG \& Bennett, EL (eds.). Hunting for sustainability in tropical forests. Columbia University Press, New York, $499-519$.

[4] BIGGS, D, COURCHAMP, F, MARTIN, R \& POSSINGHAM, HP, 2012. Legal Trade of Africa's Rhino Horns, Science 339: 1038-1039.

[5] BULTE, EH \& DAMANIA, R, 2005. An Economic Assessment of Wildlife Farming and Conservation, Cons. Biol. 19(4): 1222-1233.

[6] BULTE, EH. (2003) Open access harvesting of wildlife: the poaching pit and conservation of endangered species. Agric Econ 28, 27-37.

[7] CLARK, CW, 1990. Mathematical Bioeconomics: The Optimal Management of Renewable Resources. John Wiley \& Sons, New York.

[8] COLlins, A, FRASER, G. \& SNOWBALL, J, 2013. Rhino Poaching: Supply and Demand Uncertain, Science 340: 1167.

[9] CONVENTION ON INTERNATIONAL TRADE IN ENDANGERED SPECIES (CITES), 2013. Species trade and conservation: Rhinoceroses. Sixteenth meeting of the Conference of the Parties Bangkok (Thailand), 3-14 March 2013. CoP16 Doc. 54.2 (Rev. 1)

[10] CRAIGIE, ID, BAILliE, JEM, BALMFORD, A, CARBONE, C, COLLEN, B, GREEN, RE, HUTTON, JM, 2010. Large mammal population declines in Africa's protected areas. Biol. Conserv. 143, 2221-2228. 
[11] CROOKES, DJ \& MILNER-GULLAND, EJ, 2006. Wildlife and economic policies affecting the bushmeat trade: a framework for analysis, S. Afr. J. Wild. Res. 36(2): 159-165

[12] DEPARTMENT OF ENVIRONMENTAL AFFAIRS, 2014. Rhino poaching statistics. Department of Environmental Affairs, Pretoria.

[13] DI MININ E, LAITILA J., MONTESINO-POUZOLS F., LEADERWILliAMS N., SLOTOW R., GOODMAN P.S., CONWAY A.J., and MOILANEN A., 2015. Identification of Policies for a Sustainable Legal Trade in Rhinoceros Horn Based on Population Projection and Socioeconomic Models. Cons. Bio., In press.

[14] EDWARDS, VM, and STEINS, NA, 1999. Special issue introduction: the importance of context in common pool resource research. Journal of Environmental Policy \& Planning 1(3), 195-204.

[15] EMSLIE, RH, KNIGHT, MH, 2014. Update on African rhino status and trends: from IUCN SSC African Rhino Specialist Group (AfRSG). Report to CITES Standing Committee 65th meeting: pp. 1-6

[16] EUSTACE, M., 2012. Rhino poaching: what is the solution? Business day live, 8 August 2012

[17] EUSTACE, M. 2014, Smart trade in rhino horn is only solution to poaching. Business day live, July 212014

[18] FEENY, D, BERKES, F, MCCAY, B.J., ACHESON, JM, 1990. The tragedy of the commons: twenty-two years later. Human Ecology 18 (1), $1-19$.

[19] FERREIRA, SM, BOTHA, JM \& EMMETT, M, 2012. Anthropogenic influences on conservation values of white rhinos. Pubic Library of Science ONE. $7(9)$

[20] FERREIRA, SM \& OKITA-OUMA, B, 2012. A proposed framework for short-, medium- and long-term responses by range States to curb poaching for African rhino horns. Pachyderm 51: 52-59.

[21] FERREIRA, SM, PFAB, M, \& KNIGHT, MH, 2014. Management strategies to curb rhino poaching: an exploration of alternative options. South African Journal of Science 110(5/6), 8 pages.

[22] GAME RESERVES UNITED, 2013. Legalizing international trade in rhino horn. Submission to Department of Environmental Affairs, Pretoria.

[23] GELDMANN J, BARNES M, COAD L, CRAIGIE ID, HOCKINGS M, BURGESS, ND, 2013 Effectiveness of terrestrial protected areas in reducing habitat loss and population declines. Biol. Conserv. 161, 230-238. 
[24] HALL RJ, MILNER-GULLAND EJ, CHOURCHAMP F, 2008. Endangering the endangered: The effects of perceived rarity on species exploitation. Conservation Letters 1: 75-81

[25] HANSEN, AJ, DEFRIES, R, 2007. Ecological Mechanisms Linking Protected Areas to Surrounding Lands. Ecological Applications, 17(4), 974988

[26] HARDIN, G, 1968. The Tragedy of the Commons, Science 162: 112431248.

[27] HARDIN, G., 1998. Extensions to the tragedy of commons, Science 280 (5364): 682-683

[28] KAGANDE, SM \& MUSARURWA, LK, 2014. Conserving the African rhinoceros. J. Biodiv. Conserv. 23(2): 497-502.

[29] KALRON, N, 2013. Neo-conservation, Afr. Sec. Rev. 22: 160-166.

[30] LINDSEY, P, NYIRENDA, V, BARNES, J, BECKER, MS, MCROBB, R, TAMBLING, C, TAYLOR, A, WATSON, F, T'SAS-ROLFES, M, 2014. Underperformance of African protected area networks and the case for new conservation models: insights from Zambia. PLoS one 9, e94109.

[31] LITCHFIELD, CA, 2013. Rhino Poaching: Apply Conservation Psychology, Science 340: 1168.

[32] MESSER, KD, 2010. Protecting endangered species: When are shoot-onsight policies the only viable option to stop poaching? Ecological Economics 69: 2334-2340.

[33] MCCULLOUGH, D, 1996. Spatially structured populations and harvest theory, J. Wild. Manag. 60: 1-9.

[34] MCHENRY, TJP, 1993. Policy and Legal Tools for the Management of Wildlife Resources, Unasylva 44 (3): 46-50. FAO. Rome.

[35] MILLIKEN, T \& SHAW, J, 2012. The South Africa-Vietnam rhino horn trade nexus: A deadly combination of institutional lapses, corrupt wildlife industry professionals and Asian crime syndicates. TRAFFIC, Johannesburg.

[36] MILNER-GULLAND EJ, 1999, How many to dehorn? A model for decision-making by rhino managers, Animal Cons., Vol: 2, Pages: 137-147, ISSN: 1367-9430

[37] MILNER-GULLAND EJ, BEDDINGTON JR and LEADER-WILLIAMS, 1992. Dehorning African Rhinos: A Model of Optimal Frequency and Profitability. Proceedings: Biological Sciences, Vol. 249, No. 1324 (Jul. 22, 1992), pp. 83-87 
[38] MILNER-GULLAND E.J. \& LEADER-WILLIAMS, N., 1992. Illegal Exploitation of Wildlife. In: Swanson T, Barbier E.B. (Eds.), Economics for the Wilds. Earthscan, London, pp.195-213.

[39] OSTROM, E, BURGER, J., FIELD, CB, NORGAARD, RB, POLICANSKY, D, 1999. Sustainability - revisiting the commons: local lessons, global challenges. Science, 284: 278-82

[40] STAY IN AFRICA, 2014. Sabi Sands Game Reserve. Available at: http://www.stayinafrica.com/ (Accessed: 3 July 2014).

[41] 't SAS-ROLFES, M, 2012. The Rhino Poaching Crisis: A Market Analysis. Available at: http://savetherhinotrust.org.

[42] 't SAS-ROLFES, M., MOYLE, B, STILES, D, 2014. The complex policy issue of elephant ivory stockpile management. Pachyderm 55: 62-77

[43] TRAILL LW, BROOK BW, FRANKHAM RR, BRADSHAW CJA, 2010. Pragmatic population viability targets in a rapidly changing world. Biological Conservation 143: 28-34

[44] UNEP, 2014. Emerging Technologies: Smarter ways to fight wildlife crime. Global Environment Alert Service Bulletin, June 2014. United Nations Environment Programme. Available at: http://www.unep.org/geas/ (Accessed: 16 July 2014).

[45] WESSA, 2014. The WESSA Rhino Initiative. Available at: http://www.wessa.org.za.

[46] WILKIE, D \& CARPENTER, J, 1999. Bushmeat hunting in the Congo Basin: an assessment of impacts and options for mitigation, Biodivers. Conserv. 8: 927-955.

[47] VECCHIATO P., 2013. Government may auction stockpile of rhino horn. Business day live, 03 July 2013. 
Table 1: Framework for policy evaluation

\begin{tabular}{|c|c|c|c|}
\hline Target group & Policy & Example of policy & Key policy questions \\
\hline \multirow[t]{2}{*}{ Consumers } & $\begin{array}{l}\text { Direct market } \\
\text { interventions } \\
\text { (demand) }\end{array}$ & $\begin{array}{l}\text { Education } \\
\text { Price controls } \\
\text { Income modifications } \\
\text { Toxic treatment of horns to place } \\
\text { consumers at risk } \\
\text { Chemical treatment (e.g. dye) to deter use } \\
\text { Legal action against consumers }\end{array}$ & \multirow[t]{2}{*}{$\begin{array}{l}\text { Is there a change in preferences? } \\
\text { Is there a change in the price? } \\
\text { Is there a change in consumer } \\
\text { income? } \\
\text { Is rhino horn consumption } \\
\text { affected? }\end{array}$} \\
\hline & $\begin{array}{l}\text { Direct market } \\
\text { interventions } \\
\text { (supply) }\end{array}$ & Trade bans & \\
\hline Game reserves & $\begin{array}{l}\text { Protected areas } \\
\text { management }\end{array}$ & $\begin{array}{l}\text { Establishing private property rights } \\
\text { Establishment of buffer zones } \\
\text { Source sink policies } \\
\text { De-horning } \\
\text { DNA profiling } \\
\text { Relocation of rhino } \\
\text { Breeding of hornless rhinos }\end{array}$ & \multirow{3}{*}{$\begin{array}{l}\text { Is there a change in the costs of } \\
\text { supplying rhino horn? } \\
\text { Is there a change in the products } \\
\text { supplied? } \\
\text { Is there a constraint on supply } \\
\text { from wildlife areas? } \\
\text { Is there a change in hunter } \\
\text { behaviour? } \\
\text { Is there a change in hunter } \\
\text { livelihoods? } \\
\text { Are changes in hunter livelihoods } \\
\text { compensated for by promotion of } \\
\text { alternative activities? } \\
\\
\begin{array}{l}\text { Are earnings from alternative } \\
\text { activities sufficient to reduce the } \\
\text { incentive to poach? } \\
\text { Are alternative products sufficient } \\
\text { to encourage traders to substitute } \\
\text { away from rhino horn? } \\
\text { Are alternative livelihoods } \\
\text { adequate to ameliorate the effects } \\
\text { of profitability losses? }\end{array}\end{array}$} \\
\hline $\begin{array}{l}\text { Hunters/ } \\
\text { Poachers }\end{array}$ & $\begin{array}{l}\text { Hunter behaviour } \\
\text { modification } \\
\text { Poacher behaviour } \\
\text { modification }\end{array}$ & $\begin{array}{l}\text { Quotas } \\
\text { Hunting seasons } \\
\text { Gear restrictions } \\
\text { Species restrictions } \\
\text { Enforcement } \\
\text { Steep penalties/prison sentences } \\
\text { Shoot to kill }\end{array}$ & \\
\hline Whole supply chain & $\begin{array}{l}\text { Livelihood } \\
\text { modification } \\
\text { Intermediary } \\
\text { behaviour } \\
\text { modification }\end{array}$ & $\begin{array}{l}\text { Game ranching } \\
\text { Livestock farming } \\
\text { Other (non-farming) livelihoods } \\
\text { Alternative product development } \\
\text { Cost and price manipulaton }\end{array}$ & \\
\hline
\end{tabular}

Source: Adapted from Crookes and Milner-Gulland (2006), with additional policies from Ferreira et al (2012);

Messer (2010); Ferreira \& Okita-Ouma (2012); and Ferreira et al (2014) 
Table 2: Price of rhino horn for different suppliers

\begin{tabular}{|l|c|c|c|c|}
\hline & $\begin{array}{c}\text { Price of rhino horn } \\
(\$ / \mathrm{kg})\end{array}$ & $\begin{array}{c}\text { Share of retail } \\
(\%)\end{array}$ & $\begin{array}{c}\text { Price of rhino horn } \\
(\$ / \mathrm{kg})\end{array}$ & $\begin{array}{c}\text { Share of retail } \\
(\%)\end{array}$ \\
\hline Poachers & $1990 \mathrm{~s}$ & & 2013 & 7.7 \\
\hline Exporters & 25 & 0.4 & 5000 & 10.8 \\
\hline $\begin{array}{l}\text { Wholesal } \\
\text { e }\end{array}$ & 375 & 5.7 & 7000 & 50.0 \\
\hline Retail & 600 & 12.1 & 32500 & 100.0 \\
\hline
\end{tabular}

Source: Own calculations based on Milliken and Shaw, 2012; Vecchiatto, 2013; Eustace, 2012; Eustace, 2014.

Figure 1: The growth in incomes in Vietnam, as measured by their gross domestic product per capita, between 1980 and 2014

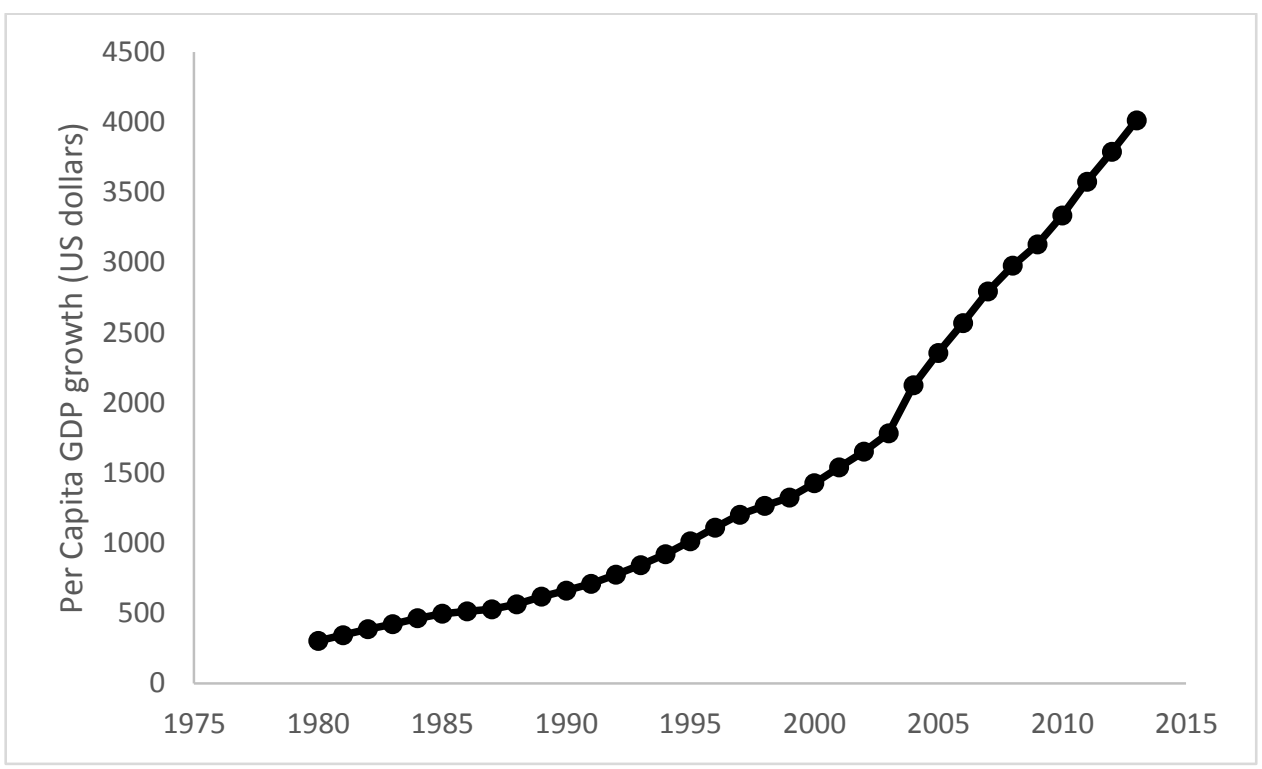


Figure 2: The policy effect of an Anthropogenic Allee Effect (AAE). At certain price ranges, the figure shows that a reduction in demand from $D$ to D1 results in an increase in price from $\mathrm{P}$ to $\mathrm{P} 1$, and an increase in yield, from $\mathrm{Y}$ to $\mathrm{Y} 1$

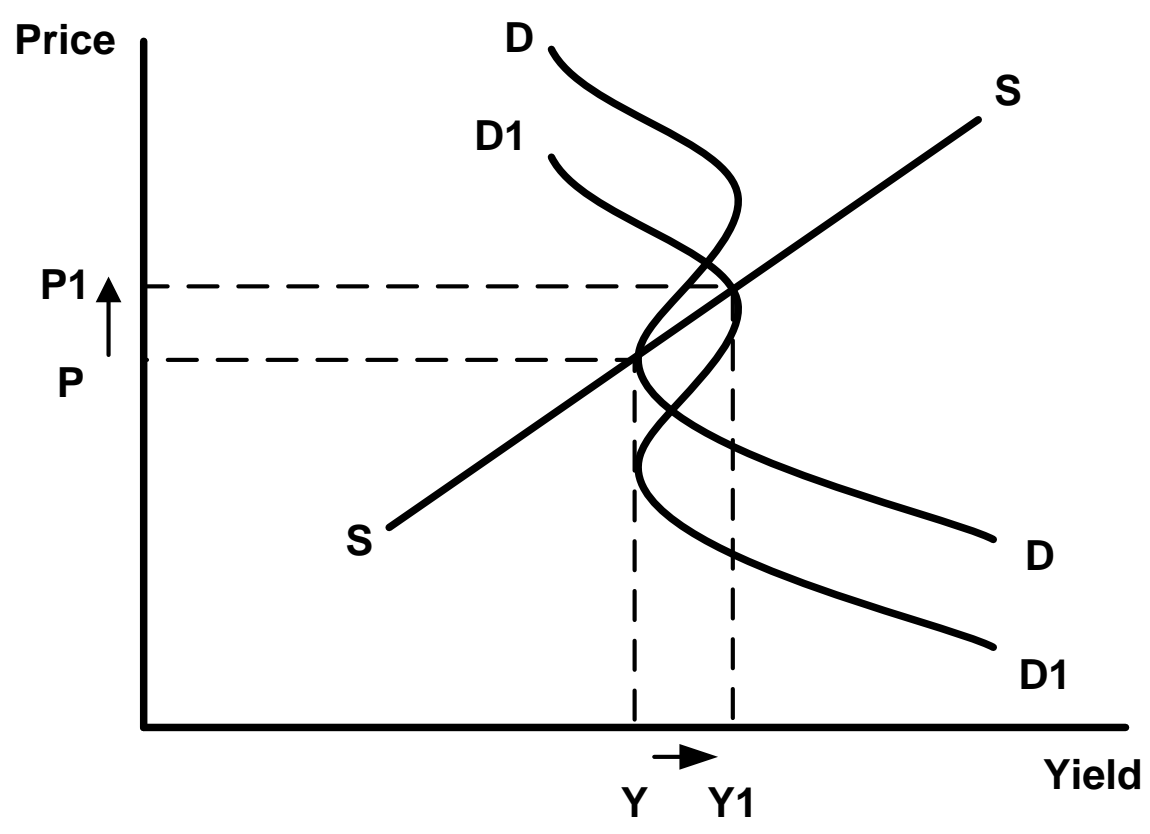

